Theory and Applications of GIS, 1997, Vol. 5, No. 1, pp. 55-62.

\title{
社会開発型ODA事業におけるGISの役割一東北夕イ造林普及計画(REX)を例 としてー
}

永田 好克、河野 泰之、吉田 憲悟、竹田 晋也

\section{Role of GIS in a Social Development ODA Project: A Case Study of the Reforestation and Extension Project in the Northeast of Thailand (REX)}

Yoshikatsu NAGATA, Yasuyuki KONO, Kengo YOSHIDA and Shinya TAKEDA

\begin{abstract}
Many countries including Japan have been conducting ODA projects in various areas. These vary from hardware-oriented projects such as engineering works to software-oriented projects, namely, social development projects, such as education and extension. The results of a hardware-oriented project are visible and easily evaluated, but those of a software-oriented project are more difficult to evaluate. The authors have been involved in the Reforestation and Extension Project in the Northeast of Thailand (REX), a softwareoriented project which aims to promote reforestation by rural villagers themselves. This project has entered its final year and the authors have tried to establish a new method to evaluate it using a GIS application. This paper introduces our trials, and then describes a model way of application of GIS in a software-oriented project.
\end{abstract}

Keywords: 東北タイ(Northeast Thailand)、社会経済データベース(Socio-economic database)、政府開発 援助(ODA)、社会開発(Social development)、造林(Reforestation)、GIS関与モデル(Model of application of GIS)

\section{1.はじめに}

現在、日本をはじめとする多くの国が、さまざま な地域で政府開発援助(ODA)を展開している。これ らの事業は、土木や建築をはじめとするハードウェ アを主体とするものから、教育や啓蒙などのソフト ウェアを主体とするものまで幅広い。ハードウェア が主体である事業の場合には事業の直接的な成果は 目に見え、その意味では評価が容易である。しか し、ソフトウェア主体の事業では、その成果を把握 するのが前者に比して難しい。ともすれば事業展開

\footnotetext{
永田：干558大阪市住吉区杉本3-3-138 大阪市立大学学術情報総合センター Media Center, Osaka City University 3-3-138, Sugimoto, Sumiyoshi, Osaka 558 Tel. 06-605-3380 Fax. 06-690-2736 E-mail: nagata@media.osaka-cu.ac.jp 河野: 京都大学東南アジア研究センター 吉田：国際協力事業団東北夕イ造林普及計画 竹田 : 京都大学農学部
}

の手段そのもの、例えば講習会の受講者数や啓蒙活 動の延べ回数などをそのまま成果とするよりほかな い状況が存在する。また、これらソフトウェア主体 の事業は数年から10年近くの長期にわたるものが多 く、事業立案段階と実際の実施期間中とでは、社会 経済環境に変容が生じていても不思議ではない。よ り効果的な展開のためには、状況変化に対して柔軟 に対応していかねばならないだろう。

筆者らが数年にわたって関与してきた国際協力事 業団(Japan International Cooperation Agency, JICA) 東 北夕イ造林普及計画(The Reforestation and Extension Project in the Northeast of Thailand, REX)は、社会開 発型すなわちソフトウェア主体事業のひとつであ り、五ヶ年計画の最終年度を迎えた。この事業にお いても、成果を測る必要には迫られながらも定まっ た手法がなく、評価方法について模索していた。 そこで筆者らは、GISのひとつとして開発してきた 
東北タイ村落情報システム(Northeast Thailand Village Information System, NETVIS) 基盤にREXの 成果を描き出すことを提案し、実際にそれを試みた (Nagata et al., 1996)。

本稿は、筆者らのREXでの試みの過程を報告し、 そこで展開された議論にGISはどのように関与し、 また有用な情報を提供しえたのかを考察する。さら に、社会開発型ODAのどの段階にGISが関与すべき かを提案する。

\section{NETVIS(東北タイ村落情報システム)}

タイ国では、内務省地域開発局 (Community Development Department, CDD)が中心となって、タ イ国全土の農村部村落を対象にした村落基礎データ 調查を行っている(Community Development Department, 1995)。これは、人口から生活環境、生 産環境、教育、公衆衛生など農村部の社会経済情報 を網羅するものであり、1986年以降2年毎に村落 データベースとしてデータベース化されている。 この中で約2万8千村落(mu ban)ある東北タイを対象 にして、村落データベースの内容を主に地図化する ためにNETVISを開発してきた(永田、1996)。

本報告では、このNETVISに、さらに造林に関す るデータを追加することによって、REXの事業評価 の用に供している。なお、この時点で利用可能で あった村落データベースは1986年、1988年、1990 年、1992年である。また、村落位置の捕捉率は、 (永田、1996)では82\%であったが、現在91\%まで改 善している。

\section{3．東北タイにおける造林事業}

\subsection{REX(東北夕イ造林普及計画)の概要}

東北タイ造林普及計画は、夕イ国王室林野局 (Royal Forest Department, RFD) とJICAにより1992年4 月から1997年3月までの5年間の予定で開始された。 ただしRFD側の資料では、関連事業が開始された 1991年度が初年度となっている。なお、タイ国の年 度は前年10月から始まる。

この事業は、東北タイ全域を対象にして住民主体 の造林をおもに私有地および村落公共地において推
進することを目的とする。当初計画では、薪炭材の 不足を基準に事業対象とするべき村落を約 5,900選定 し、さらにこれを基に5年間で2,668村落に事業を実 施する計画を作成した。これは、東北タイ全村落の 約 1 割にあたる。

REXの主たる事業内容は、苗木生産配布、普及、 訓練、展示林造成である。苗木の生産配布にあたつ ては、マハサラカム、ウドンタニ、ヤソトン、ナコ ンラチャシマの4個所に建設された苗畑センターを 核とした。樹種に関しては、地域住民の需要を反映 し、約半数はユーカリで、残りはチークやビルマカ リンなどの郷土樹種を中心とする。

\section{2. 他の事業}

現在、タイ国東北部では、REXの他に多くの造林 関連事業が進行中である。管轄する政府関連機関 も、RFDのほか、地域開発局 (CDD)、農業普及局 (Department of Agricultural Extension, DOAE)、林業 公社(Forest Industry Organization, FIO)など挙げるこ とができる。さらに人口・地域開発協会(Population and Community Development Association, PDA)に代表 される非政府組織によるものもある(赤羽、1994)。 これらの中で造林事業の主流を占めるRFDが管轄し ている事業のうち、REX以外の主なものを以下に列 挙する。

（1）農民造林普及事業（Farmers' Forest Plantation Extension Project) 1994年開始。チークなどの長伐 期の樹種を対象。

（2）農業生産棈造改善事業 (Agricultural Production System Improvement Project）1994年開始。もとも とキャッサバ耕作転換事業として始まった。キャ ッサバ耕作地や水田跡地からユーカリなどの早生 樹種植林地への転換促進。

(3) 共有林造成事業 (Community Forest Development Program) 1987年開始。

(4)トゥンクラロンハイ開発事業（Thung Kula Ronghai Development Project) 1982年開始。東北夕 イ南部のムン川沿いの広大な低地であるトゥンク ラロンハイ地域の塩害と水害を防ぐことが目的。 (5) 国王在位50周年記念植林事業 (The Permanent 


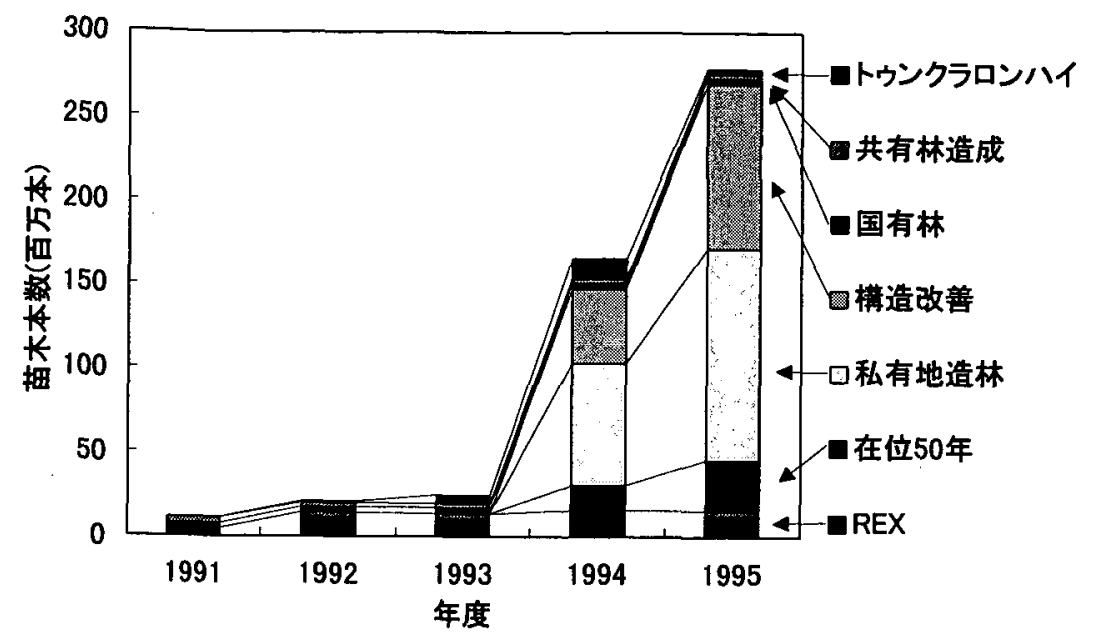

図 1 RFD管轄下の造林事業(東北タイ)

Reforestation in Commemoration to the Royal Golden Jubilee of His Majesty's Accession to the Throne) 1994 年開始。永続林として木材利用は考えていない。 郷土樹種が主体。

(6) 国有林造林事業（National Forest Reforestation） 1906年開始。RFDでは最も歴史のある造林事業。 代表的な植林樹種はチーク。

以上のうち、(1)から(4)は私有地や村落公共地を対 象としており、REXの事業対象とは重複しうる。さ らに(2)から(4)は、ユーカリが主要な樹種である。 したがって、造林対象地域では、多くの似たような 事業が同時進行している。特に1994年以降は量的に 急速に拡大し、REXの相対的な地位は低下している (図1)。

\section{4、GIS応用の試み}

4.1. 評価にあたっての背景

本年度はREXの第一期最終年度にあたり、必然的 に存在する事業評価という命題に対して、筆者らは 今年の初頭から検討を始めた。どのような資料が入 手可能か、独自にどのような項目をどのように調查 するか、そして最大の課題はどのような手法で評価 を行うかである。

もともと造林事業とは長期にわたつて取り組むべ きものであり、 5 年間といつた短期間で目にみえる ような成果を期待するのは難しい。しかも、REXの 地域住民に対する造林助成での関わりは苗木の配布
のみであり、その後の植栽管理は 住民に委小られている。事業者側 は配布時点での記録しか明確に把 握できるものがなく、いきおいそ の数字のみで評価をすることにな る。しかし、配布するのが最終目 的なのではない林地として定着し てこそ意味がある。苗木がどのよ うに取り扱われたのかを推し量る ことができればわかりやすい評価 につながるだろう。しかし、REX の事業に深く関わる私有地造林に ついての統計資料は存在しない。

\section{2. 調査票調查の立案}

利用しうる直接的な統計資料がないこと、そして 仮に得られたとしても 5 年間というこの事業の期間 から見れば、入手可能な最新データといえども充分 に新しいとは言えないことをふまえ、独自に調査し て資料を収集する必要性を認識したのは今年の初め のことである。ここで、筆者らは独自調查を行うに あたっての方針や課題を検討した。

(1) 可能な限り客観的な分析結果が得られること。 事例調査にみられるような恣意的なサンプル調查 では、全体像を客観的に分析するのには不向きで ある。

(2) REXのみの成果を調査するのは難しい。前項ま でに述べたように、東北タイには多くの造林事業 が展開しており、扱っている樹種も多くの場合ユ 一カリをはじめとして重複している。このような 状況下で、地域住民がそれぞれの事業を明確に区 別して取り扱っていることを期待するのは難しい

(3) NETVISの活用が不可欠であること。

(4) 実務上、処理可能な方法、分量であること。

以上のことをふまえ、調査票調查を行うことを REXに提案した。そして、数ヶ月にわたって調査項 目の内容や配布範囲、配布手順についてREXの特に タイ側責任者らと協議を重ね、調査票を作成した。 調査項目は、(1)村全体のユーカリ林地、(2)過去5年 間のユーカリ造林地、(3)昨年伐採したユーカリ林 
地、(4)村落内のユーカリ以外の林地及び果樹園、(5) (4)のうち過去 5 年間に造林した分であり、それぞ れ、(1)公共地、(2)私有地、(3)合計の面積を質問して いる。そのほか欄外でユーカリ材の販売価格も問う ている。

REXの苗畑センターが 4 個所あることや、ユーカ リ造林の歴史的および地域的事情を考慮の上、マハ サラカム、ヤソトン、ノンブアランプ、ブリラムの 4県を選択した。さらに結果をNETVISで地図化す ることを考慮し、4 県内全村落(約5,300)の村長を対 象とした。配布は主に行政組織ルートに委ね、4月 から 5 月にかけて順次配布を依頼した。

\section{3. 調査票回収状況}

筆者らが分析に用いたのは 9 月中旬までに回収さ れたものである。回収状況は表 1 のようになった。 これは、事前の予想にほぼ見合う回収率である。以 降も断続的に回収されており、10月下旬時点で約 26\%になっている。

\section{表 1 調查票回収率}

\begin{tabular}{|c|rcc|}
\hline 県 & 配布 & 回収 & 回収率 \\
\hline ヤソトン & 779 & 123 & $16 \%$ \\
\hline ブリラム & 2,317 & 443 & $19 \%$ \\
\hline マハサラカム & 1,603 & 518 & $32 \%$ \\
\hline ノンブアランプ & 623 & 166 & $27 \%$ \\
\hline 計 & 5,322 & 1,250 & $23 \%$ \\
\hline
\end{tabular}

しかしながら、行政ルートに委ねた配布だったた め、いくつかの郡(県の下のレベル)からは全く回収 されなかった。行政ルートの途中で滞留してしまっ たものと判断される。

回収されたものの回答内容を点検すると、分析に 支障を来たしうる大きな問題点が内包されているこ とが判明した。それは、調查対象者らが表形式の調 查票に不慣れであるということである。回答の際の 苦悩の跡が現われているものや、調査項目のこちら の意図を理解していないものが数多く見られた。

\section{4. 他の収集資料}

調查票調査のほか、造林に関連するもの、あるい は得た資料を検証するために必要な資料を収集し た。

(1) 林業統計 (Forestry Statistics of Thailand) RFDが発 行している。

(2) RFD管轄下のREXも含む各造林事業の記録統計 類。

(3) 農業統計(Agricultural Statistics of Thailand) 土地利 用統計や作目別作付け面積などが含まれる。

(4) 公共林データベース(Community Forest Database) RFDの公共林部門が調查している公共林一筆ごと のデータ。現在も調査は継続している。

\section{5. 資料分析のための準備}

8月上旬から収集した資料をNETVISに重ね合わ せることができるように整理を開始した。

最も難航したのが調査票調査結果の解釈である。 前述したような事情により、調査票に書き込まれた 回答をそのまま使用することは危険である。とはい え、この調査結果にかわってREX事業の分析をしう る資料もない。回収率がもっと高ければ疑わしい回 答を除外することも可能であるが、それでは残るも のが少ない。個々の調査票の回答精度は不十分で も、NETVISに組み入れて空間情報として議論材料 を提供する必要がある。そこで、本来統計処理には そぐわない方法であることは承知の上で、回答者の 意図をくみ取りながら調查票を一枚一枚解釈し修正 した。

また、積算が難しかったのが造林可能地面積の見 積もりである。林業統計に現われる数值は、RFDが 森林と認知した面積や国有保護林の面積にすぎず、 このほかにも造林可能地は存在する。造林の定着度 を測るには、より現実的な潜在的造林可能地を押さ えておく必要がある。しかし、潜在的造林可能地は 一つの土地利用区分としては明示されていない。そ こで、農業統計に現われる土地利用別の面積を年々 変動や経済情勢を加味した上で十分に吟味し、農家 経営地総面積から引き算することによって私有地内 における潜在的造林可能面積を算出した。

このほか、収集した関連資料のうち、郡単位で数 
值が得られているものを NETVIS 上で地 図化し、そこに現われる空間分布から原 資料の数值の検証を行い、分析に利用可 能かどうかの検討を行った。

さらに、REX事業の実施実績などを、 評価検討のための基礎資料としてNETVIS 上で地図化した。

\section{6. 資料に基づく討論}

ここまでに準備できた資料をもとに、 まず調查票調查の結果を地図化した。図 2 は一例で、マハサラカム県における私 有地造林の状況である。筆者らの長年の 現地調査の経験から、現われた地図の地 域特性を解釈し、調查票調查の結果が順 当に現状を反映していることを確認した。 また、筆者らの知見の及ばない地域の特 性については、他の資料などからの解釈 を試みた。ヒストグラムや相関図などの 統計処理により、分析に值しないと判断 した資料も出た。しかし、単にその資料 を切り捨てるのではなくなぜそのような 結果が生じているのかを検討し、資料収 集における改善点の提案も行った。

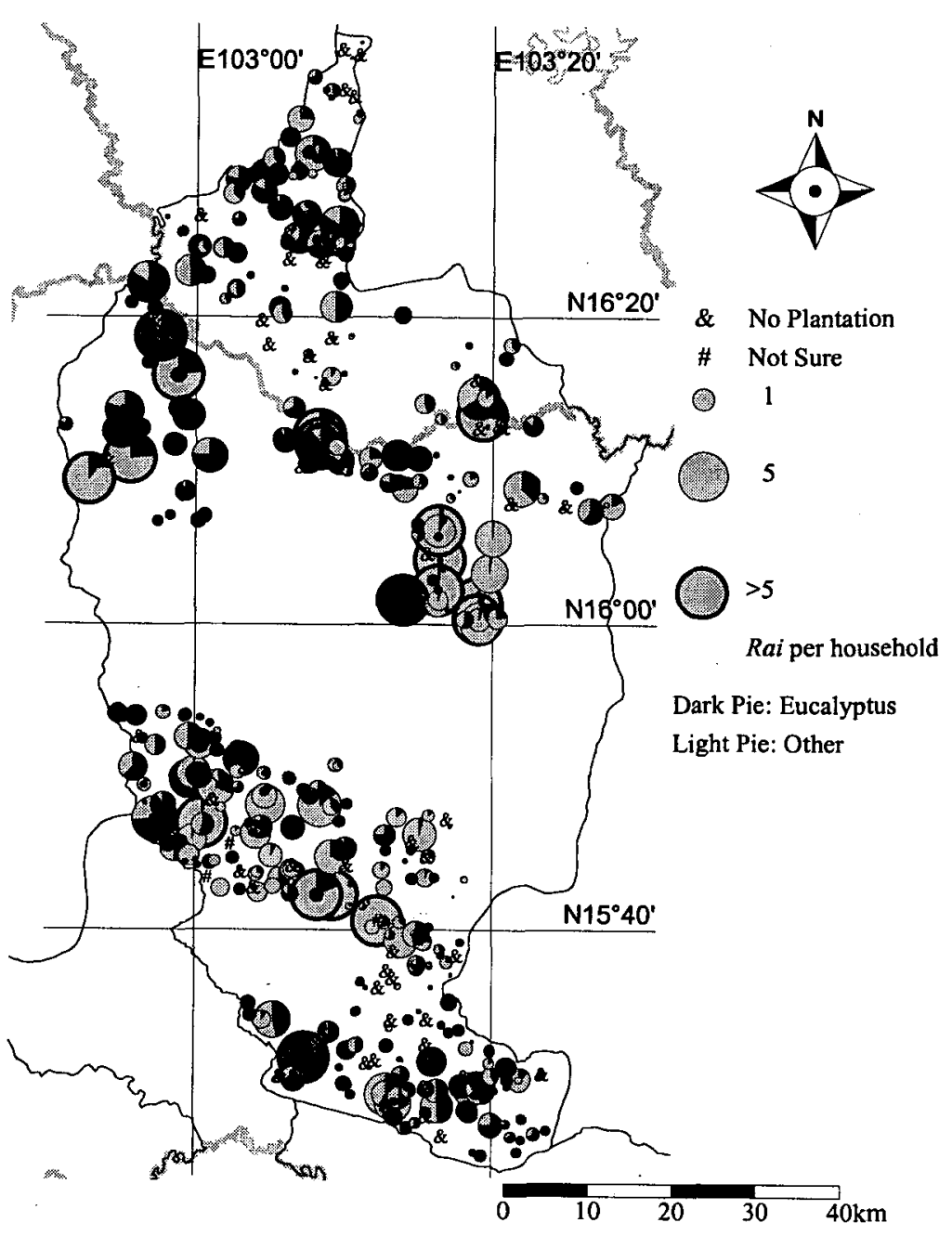

図 2 マハサラカム県の私有地造林の分布

NETVISから得られたいくつかの種類の図表を概 観し、あるいは重ね合わせ、仮説を立ててその仮説 に沿った図表を作成し、必要に応じて統計処理を 行った。新たな出力結果をもとに再び議論を行い、 また新たな仮説へとフィードバックを繰り返した。 次第に議論は収斂し、結論がまとまっていった。

\section{7. 得られた結論}

主な結論および議論結果を、以下に簡単に紹介す る。内容は、大きく分けて近年の造林動向((1) (3))、REXの春績検証 $((4) \sim(6))$ および将来予測(7)で ある。

(1) 調査票調查を行った4県での造林動向。私有地に おけるユーカリ造林に県間の差異は顕著ではない が、非ユーカリ造林では差が見られる。公共林造 林の約半分がユーカリである。

(2) 東北タイ全域での私有地造林動向の推定。調查 票調査の結果に基づいて推定を行った。その結果 現在の私有地内ユーカリ造林面積は、東北部全農 地面積の $2 \%$ を占め、その半分は過去 5 年間に造 林されたと推定される。

(3) 私有地内ユーカリ造林の立地分析。キャッサバ 耕作経営規模(図 3) とは相関性が見られるが、労 働力の過不足との相関性は薄いことが判明した。

(4) 苗木配布実績の検証。配布本数の推移や事業実 施村落の分布について図表で示し、担当者の検証 の材料とした。

(5) 他事業との比較。REXを私有地対象造林事業の 先駆者と位置づけた。

(6) REX展開地域の立地分析。他の事業や民間部門 が入りにくい、例えば、水田単作地域などの村落 へ対象を徐々に移していくこ とがREXの役割で 
あると結論 づけた。

(7) 私有地における造林拡大余 地の推定。西暦2000年までの 潜在的造林可能地面積を、 現在の耕作放棄農地拡大の傾 向がそのまま続く場合と、さ らに加速される場合とに分け て推定した。

\section{5. 考察}

図 4 に筆者らの取り組みの流 れを整理している。特に NETVIS は討論の場で大いに威 力を発揮した。仮説を設定し、 検証し、さらに別の仮説を設定 するという繰り返しの中で、仮 説を即座に視覚的に検証できる ことが、集約的効率的な討論を 可能にした。また単に地図化に とどまらず、統計処理において も村落データベース起源の

NETVISは迅速な処理結果を提供でき た。さらに REXでの報告会の場で、 NETVISの出力図は、筆者らの説明を 具体的な理解へと橋渡しするのに役 立った。

最終局面の討論の場においてGISと してのNETVISの有効性が示された が、ここにたどり着くまでの労力は 並大抵のものではない。REXの事業 記録ひとつ取っても、報告書として 文章や表中にあらわれるものを掘り 起こしデータベース化する必要が あった。年度や記録担当者によって 精度が異ることも多々ある。今回は 有効な分析資料であると判断するに は至らなかった共有林データベース も、NETVIS に重ね合わせるために 一筆一筆その位置を照合することに より活用できる可能性がある。ここ

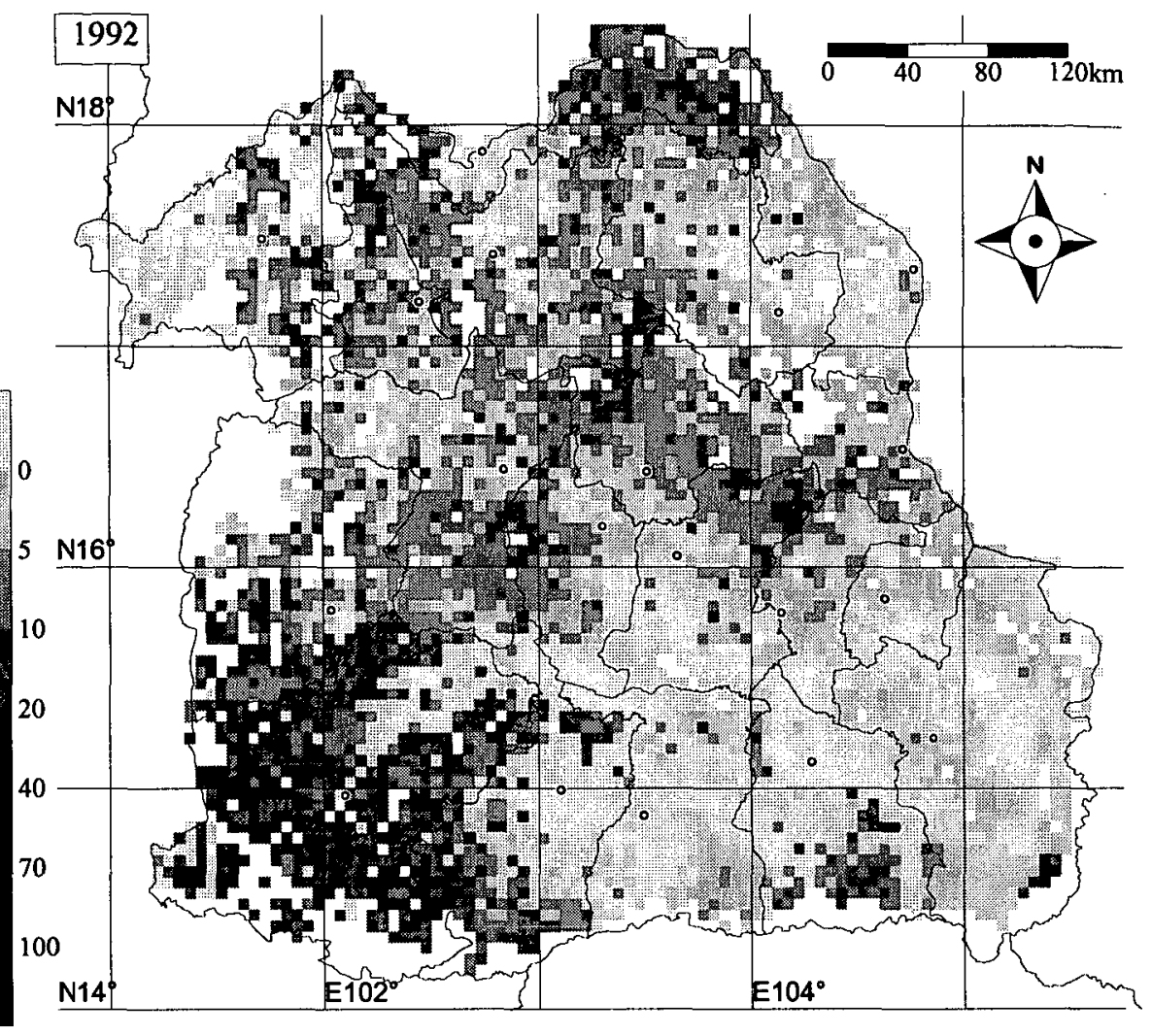

Rai per household engaged in cassava growing

図 3 キャッサバ耕作経営規模の分布

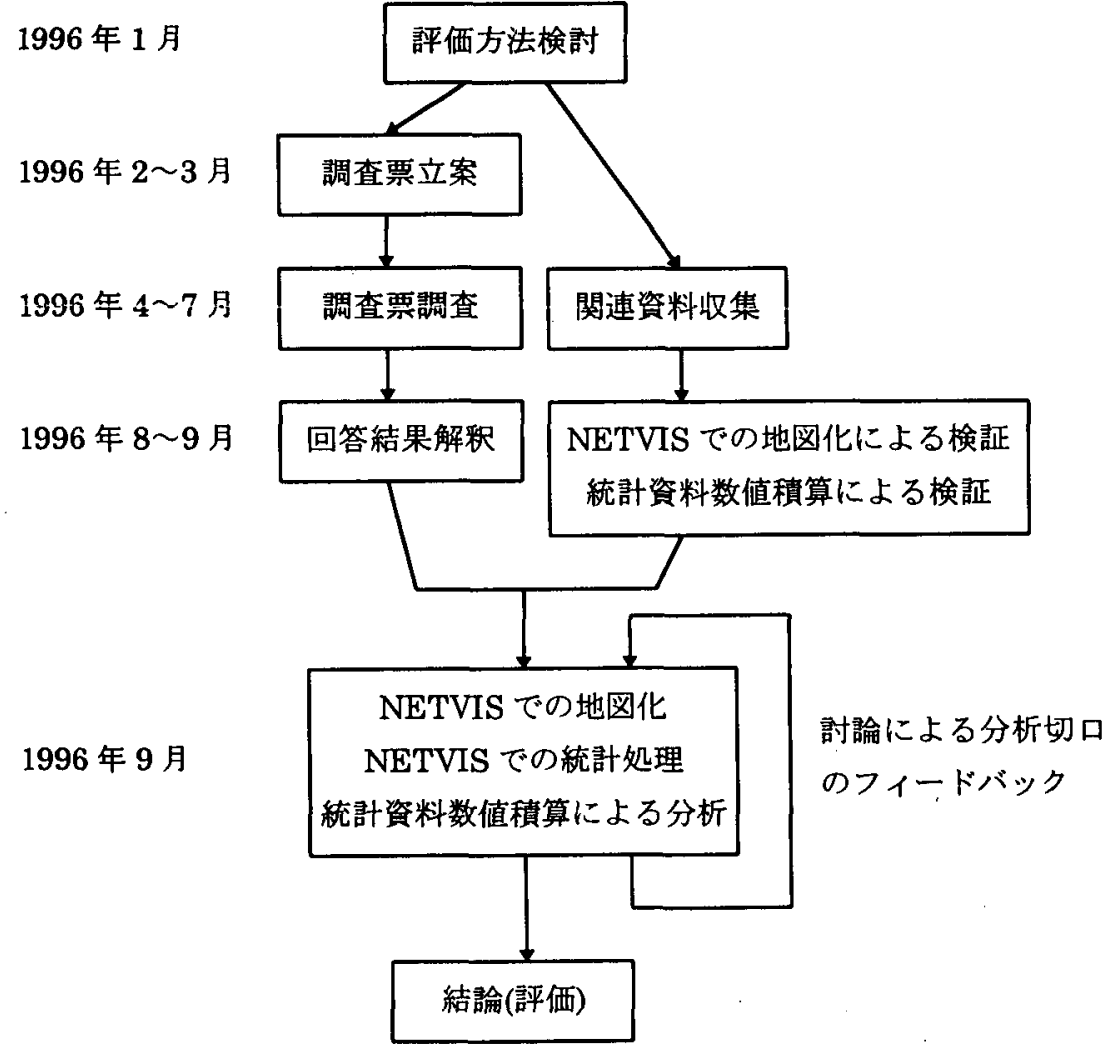

図 4 REXでの試みの流れ 
には、現在GIS用基礎 データ構築の過渡期であ るタイ国の事情も大いに 関連している(寺木、 1996)。共有すべきデータ の一般化が急がれる。

最後に、図 5 に筆者ら の経験に基づいた、社会 開発型ODAの各段階にお けるGIS関与のモデルを 提案する。これは、タイ 国における村落データ ベースのような社会経済 データベースが存在し、 なおかつNETVISのよう なGISアプリケーション が利用可能であることが 前提である。

\section{6.おわりに}

本稿では筆者らの取り 組みを具体的に述べなが らGISの果たした役割を 考察した。今回筆者らも 認識を新たにしたことで あるが、事業関係者がそ れぞれ各自理解している ことであっても、さらに 地図化して提示することによって理解が共有されあ るいは修正され、それが共通の土台となって次の議 論へと進むことである。ここにGISの真価がある。 筆者らは長らくREXに関与してきたが、もっと早い 段階でこのような議論が可能であれば、REXの事業 運営がより効果的な展開を見せていたのではないか と考えている。

今後も社会開発型のODA事業が多々展開されるこ とだろう。効果的かつ柔軟な事業企画、運営、評価 のためには、もはやGISは不可欠な存在であること をREXの事例は証明した。企画段階からGISの積極 的な活用を念頭に置き、運営中にいつでもGISを活

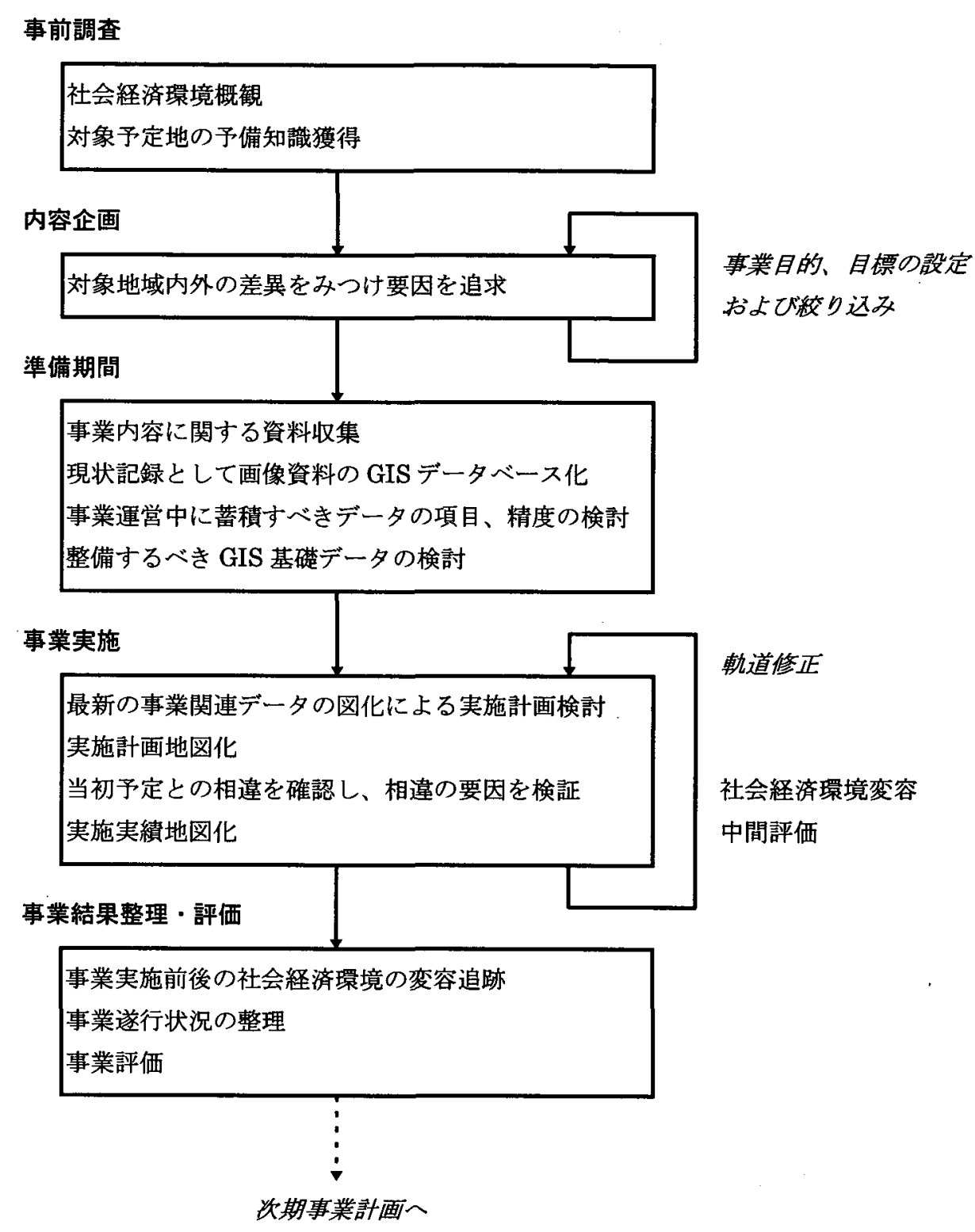

図 5 社会開発型ODAの各段階におけるGISの関与
用した議論に取り掛かれるよう、蓄積しておくべき 記録や資料を明確にしておく必要があろう。

しかしながらGISに不可欠な基礎的な地理データ を構築するのは労働集約的な作業である。GIS関連 基礎データの構築そのものを社会基盤と位置づけ、 積極的に重要なODA事業として取り組んでいくこと も必要である。

\section{謝辞}

本研究は、国際協力事業団(JICA)東北夕イ造林普 及計画(REX)での実例に基づくものである。議論の 場を提供していただき、また資料収集等において快 
くご協力いただいたREX関係者の皆様に梁くお礼申 し上げる。また、公共林データベースを提供してい ただいたRFD公共林部門のSomchai Manopiroonporn 氏にも感謝申し上げる。関連資料の整理にあたって は、一部、文部省科学研究費補助金重点領域研究 「衛星阡測」A04公募「社会・経済変容と土地利 用・農業の動態一タイ国東北部を対象としてー」(課 題番号08241109、代表者 永田好克)を利用してい る。

\section{参考文献}

赤羽武 (1994) タイにおける社会林業促進のための連 携協力体制の制度化に関する研究、『開発援助 研究セミナ一報告書』、別冊I、127-248、国際 開発高等教育機構.

寺木彰浩 (1996) タイ王国における地理情報システム の都市計画への利用状況、「GIS一理論と応 用」、4(2)、35-40.

永田好克 (1996) 村落データベースを基にした東北夕 イ村落情報システム(NETVIS)の開発、「GIS理論と応用」、4(1)、19-26.

Community Development Department (1995) Muban Chonnabot Thai pi 2537 (Villages of the Rural Areas of Thailand, 1994), Bangkok: Community Development Department.

Nagata Y., Yoshida K., Takeda S., Kono Y. (1996) Application of NETVIS to the evaluation of a reforestation project in Northeast Thailand, Proceedings of the 17th Asian Conference on Remote Sensing, E.3.1-6, Colombo: Asian Association on Remote Sensing. 